\title{
CMA1 wt Allele
}

National Cancer Institute

\section{Source}

National Cancer Institute. CMA1 wt Allele. NCI Thesaurus. Code C124244.

Human CMA1 wild-type allele is located in the vicinity of $14 q 11.2$ and is approximately 3 $\mathrm{kb}$ in length. This allele, which encodes chymase protein, is involved in the metabolism of both vasoactive peptides and the extracellular matrix. 